\title{
A FUNÇÃO SOCIOAMBIENTAL DA PROPRIEDADE: A COMPENSAÇÃO AMBIENTAL COMO DECORRÊNCIA DO PRINCÍPIO DO USUÁRIO PAGADOR
}

\section{THE FUNCTION OF SOCIAL ENVIRONMENTAL PROPERTY: THE ENVIRONMENTAL COMPENSATION AS A RESULT OF PRINCIPLE OF PAYING USER}

\author{
Mauricio Mota ${ }^{1}$
}

\section{Resumo}

Este artigo tem por objetivo demonstrar que o proprietário do bem socioambiental, ou seja, daquele bem essencial para a manutenção da vida das espécies, fica obrigado a um comportamento ativo, que envolve defender, reparar e preservar o meio ambiente. O proprietário não pode exercer o seu direito de forma contrária aos interesses da presente e das futuras gerações, causando danos à qualidade de vida e consequentemente ao próprio direito fundamental à vida. A função socioambiental da propriedade está claramente contemplada nos arts. 225 e 170 da Constituição Federal. Correlacionando-a com o instituto da compensação ambiental, verifica-se que o direito de propriedade deverá ser exercido em função do direito de toda a coletividade a um meio ambiente ecologicamente equilibrado. Este só merecerá tutela jurídica enquanto funcionalizar esse direito difuso de todos.

Palavras-chave: Função socioambiental da propriedade. Compensação ambiental. Princípio do usuário pagador. Direito das futuras gerações. Meio ambiente ecologicamente equilibrado.

\section{Abstract}

This article aims to demonstrate that the owner of the environmental good, that is, that good essential for sustaining life of the species, is bound to an active behavior, which involves defending, repair and preserve the environment. The owner can not exercise their right in a manner contrary to the interests of the present and the future generations, causing damage to the quality of life and consequently to the very basic right to life. The environmental function of property is clearly contemplated in arts. 225 and 170 of the Federal Constitution. Correlating it with the environmental compensation institute, it appears that property rights must be exercised on the basis of the right of every community to an ecologically balanced environment. This property right only merite legal protection while functionalize this diffuse rights of all.

Keywords: Social and environmental function of property. Environmental compensation. Principle of paying user. Right of future generations. Ecologically balanced environment.

\footnotetext{
1 Doutor em Direito pela Universidade do Estado do Rio de Janeiro - UERJ. Professor do Mestrado e Doutorado em Direito da Universidade do Estado do Rio de Janeiro, Professor do Doutorado em Meio Ambiente da Universidade do Estado do Rio de Janeiro, Professor Adjunto da Universidade do Estado do Rio de Janeiro e Procurador do Estado. E-mail: mjmota1@gmail.com
} 


\section{INTRODUÇÃO}

A definição e concretização dos direitos fundamentais de terceira geração, e, num particular, os direitos relacionados ao meio ambiente, vêm propondo novos desafios e impasses para o direito, muito porque tais direitos decorrem de um novo contexto social, cultural, econômico e histórico, de onde derivam novos problemas e demandas que até então nunca haviam sido enfrentados. Questões como o custo do uso dos recursos naturais, a plena reparabilidade dos danos ambientais, o direito ao meio ambiente saudável das gerações futuras, a equidade intergeracional, o objeto a ser preservado nos diversos ecossistemas, toda essa complexidade exige não só uma rigorosa definição do que seja a natureza e o gênero de direito a esta associado, mas também o debate e a proposta de soluções concretas para esses impasses.

Se concebermos o direito como os antigos gregos, ou seja, como algo decorrente da ordem da natureza e ordenado por um determinado princípio e, mais do que isso, como aquilo que cabe a uma determinada sociedade segundo uma apropriação resultante da disciplina da polis, um produto ou resultado, de acordo com uma justa medida - nem mais, nem menos, do que lhe corresponde no todo social -, podemos vislumbrar um princípio de resposta à questão das externalidades ambientais.

Em outras palavras, muito embora o meio ambiente não se configure como um titular autônomo de direitos, o seu uso - cada vez mais exaustivo e exponencialmente degradante - leva à reflexão acerca da atribuição de uma justa medida do uso dos bens ambientais, que na grande maioria das vezes não consegue ser adequadamente resguardado através dos instrumentos jurídicos tradicionais disponíveis. Assim, a disciplina da compensação ambiental, mesmo sem estar precisamente delineada teoricamente, vem se afigurando doutrinariamente como uma retribuição adequada pelo exercício concentrado e particular de um direito difuso ao meio ambiente ecologicamente equilibrado (art. 225 da CF/88). A lógica do instituto decorre, fundamentalmente, do reconhecimento de que a propriedade possui uma função socioambiental, capaz de instruir e conformar a noção de "usuário pagador".

A função socioambiental da propriedade, nesse diapasão, funcionaliza o exercício do direito de propriedade a interesses extra proprietários, como a preservação do meio ambiente, consoante o que dispõe o caput do artigo 1.228 do Código Civil. Nesse sentido, entende-se que os custos devem integrar previamente a própria concepção do direito (subjetivo) fundamental, isto é, os custos devem ser trazidos para o respectivo conceito, conduzindo a uma noção pragmática de direito subjetivo fundamental. O reconhecimento de que todos os direitos envolvem custos quase sempre elevados e de que os recursos públicos são insuficientes para a promoção de todos os ideais sociais - impondo-se 
o sacrifício de alguns deles -, implica também o reconhecimento de que tais direitos devem ser exercitados com responsabilidade.

No presente artigo, procurar-se-á identificar que a propriedade cumpre também uma função socioambiental e esta função contribui para a construção da noção de compensação ambiental como uma decorrência do princípio do usuário-pagador.

\section{A COMPENSAÇÃO AMBIENTAL}

A compensação ambiental foi introduzida no ordenamento jurídico brasileiro pela Resolução CONAMA n. 10/1987 - a qual, quase 10 anos depois, foi revogada e substituída pela Resolução CONAMA n.․ 02, de 18 de abril de 1996. De início a compensação ambiental tinha um alcance menor do que o atual, sendo exigida apenas dos empreendimentos que pudessem destruir florestas e outros ecossistemas (e não o meio ambiente como um todo, o que deixava de lado, por exemplo, o meio ambiente cultural e do trabalho), em favor da implantação de uma Estação Ecológica (e não das unidades de conservação do grupo de proteção integral). Nesse sentido, a Resolução CONAMA n.․ 02/1996 ampliou o objeto da compensação ambiental, permitindo que os recursos desembolsados pelo empreendedor a esse título fossem aplicados em outras unidades de conservação públicas de proteção integral (de uso indireto) que não, exclusivamente, as estações ecológicas.

Finalmente, o art. 36 da Lei n.o 9.985, de 18 de julho de 2000 (que institui o Sistema Nacional das Unidades de Conservação - SNUC), disciplinou o instituto da compensação, em termos legais. A regulamentação deste artigo veio pelo Decreto $n$. o 4.340, de 22 de agosto de 2002 e pela Resolução do CONAMA n. 371, de 05 de abril de 2006 (que, inclusive, revogou expressamente a Resolução CONAMA 02/1996). Cumpre mencionar também os atos normativos baixados pelo Instituto Brasileiro de Meio Ambiente e Recursos Naturais Renováveis (IBAMA) com vistas à criação e implantação da Câmara de Compensação Ambiental (Portaria n. 7, de 19 de janeiro de 2004, e Portaria n.o 44, de 22 de abril de 2004) e gestão da compensação ambiental (Instrução Normativa n.o 47-N, de 31 de agosto de 2004).

Uma das maiores preocupações atuais entre os empreendedores refere-se a identificar quais empreendimentos devem ou não apresentar EPIA/RIMA². Isto porque, no critério adotado atualmente pela Lei n.o 9.985/2000, só se cogita a exigência da compensação ambiental para aqueles

\footnotetext{
${ }^{2}$ O Estudo Prévio de Impacto Ambiental consiste em estudo multidisciplinar que indica os pontos favoráveis e desfavoráveis de determinado empreendimento e sugere medidas de mitigação dos impactos ambientais. Este estudo materializa o princípio da prevenção. O Relatório de Impacto sobre o Meio Ambiente (RIMA) deverá conter as conclusões do estudo, demonstrando em linguagem acessível à toda a comunidade todas as vantagens e desvantagens, ambientais, sociais e econômicas. Deve-se valer de quadros, tabelas, audiovisuais e simulações que facilitem a sua compreensão. Como norma, ficarão à disposição das pessoas interessadas.
} 
empreendimentos de significativo impacto ambiental que, no procedimento de licenciamento ambiental, devem promover o EPIA/RIMA. No entanto, a confusão não procede, vez que, como se destacou, a lei determina que os empreendimentos que realizarem EPIA/RIMA estão sujeitos à compensação ambiental, de modo que, a contrario sensu, aqueles empreendimentos dispensados do EPIA/RIMA não precisam se preocupar com a compensação ambiental de que trata o art. 36 da Lei do SNUC.

Na ADI n.o 3.378/DF, a Confederação Nacional da Indústria (CNI), autora da referida ação, alegou, em síntese, que:

1. o art. 36 da Lei n.o 9.985/2000feria o princípio da legalidade, pois delegava a órgão administrativo a fixação da compensação ambiental devida pelo empreendedor;

2. essa delegação promovida pelo ato normativo questionado seria ilegítima, pois estaria violando o princípio da divisão e harmonia entre os poderes;

3. a compensação seria paga apenas por empreendimentos que conseguiram licenciamento ambiental, ou seja, aqueles em que não há dano significativo, não sendo razoável a cobrança da compensação;

4. a indenização representa reparação pelos danos causados, sendo imprescindível a prévia ocorrência e a prévia valoração desses danos sob pena de locupletação por parte do Estado, com violação ao princípio da proporcionalidade; e

5. haveria ofensa aos arts. 5, II, e 37, caput, da CF/1988.

A decisão do Supremo Tribunal Federal, da lavra do Ministro Carlos Ayres Britto, começa por salientar que todos têm direito ao meio ambiente ecologicamente equilibrado, bem de uso comum do povo e essencial à sadia qualidade de vida, impondo-se ao Poder Público e à coletividade o dever de defendê-lo e preservá-lo para as presentes e futuras gerações (art. 225, caput, da CF).

Deste modo, os bens, embora tenham titularidades específicas (públicas ou particulares), em seu aspecto ambiental são de utilização comum de todos ${ }^{3}$, o que se coaduna com sua natureza de direito difuso. Portanto, sendo o uso dos bens, ambientalmente considerados, comum a todos,

\footnotetext{
3 "O proprietário do bem socioambiental, ou seja, daquele bem essencial para a manutenção da vida de todas as espécies e de todas as culturas, fica sujeito aos comportamentos apontados. Há um direito à preservação do bem, que é superior ao direito individual de propriedade. É o que chamamos de direito socioambiental de titularidade difusa. A proteção volta-se para o bem, pouco importando a sua titularidade no caso concreto. Por isso, o bem público está sujeito às mesmas regras do bem privado e os direitos socioambientais são exercidos sobre bens alheios. O bem socioambiental comporta dupla titularidade, a do próprio bem considerado materialmente e a sua representatividade em relação aos demais, compondo o chamado meio ecologicamente equilibrado. Teremos um direito de titularidade individual, o direito de propriedade, e o direito difuso para garantia socioambiental. Tais direitos devem conviver em harmonia". LEMOS, Patrícia Faga Iglecias. Meio ambiente e responsabilidade civil do proprietário: análise do nexo causal. São Paulo: Revista dos Tribunais, 2008, p. 82.
} 
incumbe a todos os envolvidos (particulares e Poder Público) compartilhar as despesas concernentes à prevenção do significativo impacto ambiental decorrente do empreendimento, a par das medidas oficiais também adotadas para tal fim. Isso porque a responsabilidade incumbe, na forma da Constituição, simultaneamente ao Poder Público e ao particular, se este utilizou os recursos naturais do entorno ou afetou o ecossistema mais intensamente, a ponto de construir empreendimento que cause significativo impacto ambiental. Cabe ao particular, na proporção da atividade por ele despendida - apurada através EPIA/RIMA -, reinternalizar tais custos no bojo de seu empreendimento, por meio do respectivo compartilhamento ou compensação, na medida de sua utilização maior, em detrimento dos demais titulares do mesmo direito difuso ao meio ambiente ecologicamente equilibrado e das futuras gerações.

A compensação-compartilhamento será estabelecida por arbitramento do órgão ambiental licenciador e foi instituída pela própria lei, não havendo assim que se falar em contrariedade ao princípio da legalidade. A compensação ambiental, no dizer do acórdão do STF, densifica o princípio do usuário-pagador ${ }^{4}$, que representa um mecanismo de assunção da responsabilidade social partilhada pelos custos ambientais derivados da atividade econômica.

Do mesmo modo, o Tribunal afastou a alegação de delegação ilegítima de poderes ao Poder Executivo para fixação do quantum da compensação, importando no estabelecimento de obrigação ao particular sem amparo em lei. Isto se deve ao fato de que a compensação-compartilhamento, além de realizar a finalidade prevista no art. 225, caput, CF/1988, não seria fixada de modo arbitrário pelos órgãos ambientais do Poder Executivo, mas estaria quantificada objetivamente, de acordo com a compostura (retribuição da maior utilização, como se vê) do impacto ambiental que vier a ser dimensionado estritamente nos dados técnicos do EPIA/RIMA. Portanto, a própria lei criou um critério objetivo, o quantum de impacto ambiental, que não é determinado a priori, mas é determinável a partir do estudo técnico do EPIA/RIMA.

Insiste o aresto que a inexistência de efetivo dano ambiental não importa em isenção do empreendedor de obrigação de partilha dos custos de medidas preventivas. Isto ocorre porque o princípio do usuário pagador implica que o só fato da alteração ambiental negativa da totalidade do meio ambiente circundante em decorrência do empreendimento, já importa em utilização diferenciada, e, consequentemente, no dever de compensar os demais, dado o caráter de compartilhamento indivisível do meio ambiente entre todos e também com as próximas gerações. Em um empreendimento que cause significativo impacto ambiental, tem-se o conflito entre dois direitos

\footnotetext{
${ }^{4}$ O princípio do usuário pagador está expresso na Lei no 9.433, de 08 de janeiro de 1997 que prevê que os recursos ambientais são escassos (art. 1) e que, aquele que os utiliza mais, em detrimento dos demais, deve arcar com o correlativo ônus pelo seu uso intensivo.
}

Revista de Direito da Cidade, vol.07, no 02. ISSN 2317-7721 pp.776-803 780 
fundamentais, o direito à livre iniciativa/desenvolvimento econômico e o direito ao meio ambiente ecologicamente equilibrado. Da composição necessária entre esses dois direitos resulta uma situação jurídica que implica na consecução da obra, mas, também, na alteração adversa das características do meio ambiente que existia anteriormente. Esse desnível entre a realidade ambiental antes existente e a atual deve ser compensado. Nestes casos, o impacto ambiental é significativo e o meio ambiente deve ser recomposto.

Assim, para o STF, a alegação de irrazoabilidade da situação e quebra de isonomia porque a compensação seria paga apenas por empreendimentos que conseguiram licenciamento ambiental (ou seja, aqueles em que, em princípio, o dano poderia ser mitigado) não tem procedência, dado que mesmo sendo lícita a atividade, existe o dever de compensação. Inspirando-se na decisão, é de se cogitar que ainda que a atividade seja lícita, como na construção de obras públicas, por exemplo, quando esta atinge o direito de alguns de igualdade na distribuição dos encargos públicos, é gerado o dever de ressarcimento. Do mesmo modo, em se tratando de um direito difuso de todos ao meio ecologicamente equilibrado, quando o direito da coletividade se vê diminuído pela alteração adversa das características do meio ambiente, embora lícita, há o dever de compensação que se instrumentaliza pela compensação ambiental legal. O usufruto maior do meio ambiente por parte de alguns importa no usufruto menor por parte dos demais, daí a obrigação de compensação devido ao compartilhamento do mesmo direito.

O acórdão ressalta a eficácia do meio empregado, o compartilhamento, para densificar a responsabilidade do empreendedor perante a coletividade difusa, titular do mesmo direito ao meio ambiente ecologicamente equilibrado, sendo o desiderato de tudo a permanência da higidez do meio ambiente, apesar das necessidades próprias ao desenvolvimento humano.

A decisão rejeitou expressamente, ainda, a argumentação do Ministro Marco Aurélio de que a compensação ambiental tenha natureza indenizatória. Sua natureza é compensatória, dado que visa à preservação do meio ambiente, no sentido de um desenvolvimento sustentável. O montante de recursos a ser destinado deve ser fixado de acordo com o grau de impacto ambiental, revelado em perícia técnica (EIA/RIMA), que permita escaloná-lo, sem relação necessária como custo total do empreendimento. A decisão também previu que deve haver um nexo de causalidade entre a preservação almejada e o impacto ambiental gerado pelo empreendimento. O Supremo considerou, assim, não procedente a alegação de que a compensação tivesse natureza indenizatória. Logo, para a imposição legal da compensação ambiental, não seria imprescindível a prévia ocorrência e valoração dos danos ambientais, uma vez que esta não representa reparação pelos danos causados. 
Assim, na nova interpretação do Supremo Tribunal Federal, a compensação ambiental tem um limite material no potencial de impacto ambiental e na suscetibilidade ambiental da área de localização do empreendimento ou atividade. A decisão do Supremo, ainda a ser esclarecida mediante apreciação de Embargos de Declaração, direciona-se no sentido da conciliação entre o direito ao desenvolvimento e a preservação do meio ambiente, constituindo a compensação em medida mitigadora quando a prevenção de impactos não é possível e a minimização dos mesmos não é suficiente. Uma vez que o empreendimento precisa utilizar-se dos recursos ambientais de maneira mais intensa para ser realizado, o que fragiliza a fruição do direito ao meio ambiente ecologicamente equilibrado dos demais titulares do mesmo direito difuso indivisível, cabe ao empreendedor compartilhar os custos desse ônus, imposto a toda a coletividade, através da compensação ambiental.

A decisão do Supremo Tribunal Federal, através de uma declaração parcial de inconstitucionalidade com redução de texto suprimiu, ainda, a apriorística fixação de percentual mínimo sobre o custo do empreendimento, no montante de meio por cento dos custos totais previstos para a implantação do empreendimento, prevista no parágrafo primeiro do art. 36 da Lei n.o 9.985/2000. Tal disposição permite que o órgão licenciador defina o valor do financiamento compartilhado em estrita conformidade com os dados técnicos do EIA/RIMA, aptos a apurar, com a necessária precisão, o grau de impacto ambiental provado pela implantação do empreendimento. Entendeu o Pretório Excelso que o custo do empreendimento não é o critério adequado para a determinação do quantum da compensação ambiental, mas sim o impacto (perda) do meio ambiente, apurável através do EPIA/RIMA.

Nada obstante, a importante decisão não discorre sobre aquilo que the subjaz: o reconhecimento de que a compensação ambiental representa uma contrapartida, financeira ou de outra natureza, pelo impacto nos bens ambientais decorrente do desenvolvimento de um empreendimento ou de uma atividade econômica. Além disso, a compensação cumpre o papel de compensar os demais titulares do direito difuso ao meio ambiente ecologicamente equilibrado pelas externalidades provocadas pela nova instalação. Em suma, trata-se de um instrumento econômico, imposto por norma legal, de gestão do meio ambiente. A seu turno, deve-se observar que o julgamento do Supremo reconhece, ainda que implicitamente, que o direito subjetivo deve incluir a perspectiva dos custos. A função socioambiental da propriedade funcionaliza o exercício do direito de propriedade a interesses extra proprietários, como a preservação do meio ambiente, consoante o que dispõe o caput do art. 1.228 do Código Civil.

Os custos devem integrar previamente a própria concepção do direito (subjetivo) fundamental, isto é, os custos devem ser trazidos para o respectivo conceito, conduzindo a um 
conceito pragmático de direito subjetivo fundamental. O reconhecimento de que todos os direitos possuem custos quase sempre elevados, sendo custeados por escassos recursos captados na coletividade de indivíduos singularmente considerados, e de que os recursos públicos são insuficientes para a promoção de todos os ideais sociais - impondo o sacrifício de alguns deles -, implica também o reconhecimento de que os direitos devem ser exercitados com responsabilidade 5 .

O acórdão, não obstante intua as considerações sociais e existenciais acerca da função socioambiental da propriedade, aferra-se na discussão do tema da existência prévia de dano, como se de responsabilidade civil se tratasse. Na verdade, o tema é outro. Trata-se da apuração pelo EPIA/RIMA dos custos do direito difuso ao meio ambiente. Se o empreendimento necessariamente provoca um impacto ambiental negativo significativo e se este não pode ser prevenido ou mitigado sem que o próprio empreendimento não se desfaça (pense-se em uma hidrelétrica), a totalidade da coletividade - detentora do mesmo direito difuso ao meio ambiente - deve ser compensada. Isto deverá se dar em consonância com os custos desse direito, que nada mais são do que a diferença entre o que existia anteriormente e o impacto ambiental gerado pelo empreendimento.

Desse modo, as perguntas que devem ser feitas, para a plena inteligibilidade do decisum, são aquelas relativas aos fundamentos teóricos da função socioambiental da propriedade. A primeira delas concerne à existência de um direito dos homens à apropriação em comum dos bens ambientais e à destinação de tais bens a uma finalidade comum a partir da função socioambiental da propriedade. A seguir, caracterizado que a finalidade comum e preservação do meio ambiente são ínsitas ao direito de propriedade e que a sua consubstanciação é a fruição igualitária em comum do mesmo direito transindividual e indivisível, a segunda pergunta a ser respondida pode ser assim formulada: sendo a primeira premissa verdadeira, por que a compensação ambiental não seria um instituto de responsabilidade civil, como parece indicar o voto do Ministro Marco Aurélio no mencionado precedente ${ }^{6}$ ? Apesar de o voto do ilustre Ministro apontar nesse sentido, a conclusão do acórdão é peremptória em outro, como expresso no voto do Ministro Relator:

\footnotetext{
${ }^{5}$ GALDINO, Flávio. Introdução à teoria dos custos dos direitos: direitos não nascem em árvores. Rio de Janeiro: Lumen Juris, 2005, p. 213-214.

6 “De início surge o conflito do § 1o do artigo 36 da Lei n.o 9.985/2000 com o § 20 e o § ३o do artigo 225 da Carta Federal. Enquanto estes versam situações já ocorridas - a circunstância de a atividade desenvolvida pela pessoa natural mostrar-se agressiva ao meio ambiente, contendo o § 3 o a alusão até mesmo a infratores, a sanções penais e administrativas, a indenizações por danos causados - a norma atacada despreza, por completo, esses fatos geradores do ônus a ser imposto, que ganha contornos compensatórios. Prevê que o empreendedor, na fase embrionária do planejamento da atividade, visando à obtenção de licença, destinará recursos para implantação e manutenção de unidade de conservação do grupo de proteção integral, sendo o dispêndio realizado segundo preceitos da lei e o regulamento respectivo. Em síntese, há imposição de desembolso para obter-se a licença, sem mesmo saber-se da extensão de danos causados. Mais do que isso, em desprezo total ao princípio da razão suficiente, estabelece, como base de incidência do percentual a ser fixado pelo órgão
} 
Entendo que $\mathrm{o}$ art. 36 da lei n.o 9.985/00 densifica o princípio do usuário-pagador, este a significar um mecanismo de assunção da responsabilidade social (partilhada, insiste-se) pelos custos ambientais derivados da atividade econômica.

Nessa ampla moldura, é de se inferir que o fato de, aqui e ali, inexistir efetivo dano ambiental não significa isenção do empreendedor em partilhar os custos das medidas preventivas. Isto porque uma das vertentes do princípio usuário-pagador é a que impõe ao empreendedor o dever de também responder pelas medidas de prevenção de impactos ambientais que possam decorrer, significativamente, da implementação de sua empreitada econômica. Porque a compensação ambiental se revela como instrumento adequado ao fim visado pela Carta Magna: a defesa e a preservação do meio ambiente para as presentes e futuras gerações, respectivamente... não há outro meio eficaz para atingir essa finalidade constitucional senão impondo ao empreendedor o dever de arcar, ao menos em parte, com os custos da prevenção, controle e reparação dos impactos negativos ao meio ambiente.... porque o encargo financeiro imposto (a compensação ambiental) é amplamente compensado pelos benefícios que sempre resultam de um meio ambiente ecologicamente garantido na sua higidez (fls. 252).

Respondidas essas indagações, deve-se esclarecer, ainda, em que consiste a noção do usuário pagador - consoante a análise econômica do direito -, qual a natureza jurídica da compensação ambiental e, por fim, como esta se constitui em um instituto concretizador da função socioambiental da propriedade.

\section{A NATUREZA JURÍDICA DA COMPENSAÇÃO AMBIENTAL}

Controversa se apresenta na doutrina a natureza jurídica da compensação ambiental prevista na Lei $n$. o 9.985/2000, regulamentada pelo Decreto n. 4.340/2002. Dissentem os autores em classificá-la como preço público, tributo ou indenização ${ }^{7}$. Inicialmente cabe excluir a ideia de simples responsabilidade civil, na modalidade reparação de danos antecipada, porque, como vimos, a compensação ambiental vai muito além desse instituto, abrangendo também a precaução, a prevenção e o diferimento do dano no tempo.

\section{A compensação ambiental como preço público}

Ricardo Carneiro defende a tese de que a compensação ambiental seria um preço público, pelo qual o empreendedor estaria remunerando a União Federal pela exploração ou pelo uso de um

licenciador, os custos totais previstos para a implantação do empreendimento e não o possível dano verificado (fls. 259)."

${ }^{7}$ GUERRA, Sérgio. Compensação ambiental nos empreendimentos de significativo impacto. In: WERNECK, Mário et alli (Coords.). Direito ambiental visto por nós advogados. Belo Horizonte: Del Rey, 2005, p. 135-145. 
bem a ela pertencente ${ }^{8}$.Teríamos, então, uma modalidade de compensação financeira pelo uso do patrimônio público, com a mesma natureza (preço público) da Compensação Financeira pela Extração Mineral - CFEM, prevista no art. 20 da Constituição Federal. Nos termos da lei, assegura-se aos Estados, ao Distrito Federal e aos Municípios, bem como a órgãos da administração direta da União, participação no resultado da exploração de petróleo ou gás natural, de recursos hídricos para fins de geração de energia elétrica e de outros recursos minerais no respectivo território, plataforma continental, mar territorial ou zona econômica exclusiva, ou compensação financeira por essa exploração ${ }^{9}$.Preço público, na realidade, é receita originária, que provém da exploração do patrimônio público ou do desempenho de atividades comerciais, financeiras ou industriais, direta ou indiretamente, pelos órgãos da Administração Pública, com arrimo no artigo 173, da Constituição. A compensação ambiental, contudo, não objetiva a cobrança pelo uso de um bem público, pois o meio ambiente não é um bem do Poder Público, mas sim um direito fundamental de todos, intangível, cuja alteração gera uma obrigação de reparação do direito comum compartilhado.

Não caberia também se falar em preço público porque há uma diferença marcante entre a compensação ambiental (art. 36 da Lei n.o 9.985/2000) e a figura chamada pela Lei n 7.990/1989 de "compensação financeira". No caso da exação prevista na Lei n 7.990/1989, a obrigação é de recolher determinada quantia aos cofres públicos (preço), enquanto a compensação ambiental, conforme interpretação do STF, engendra uma obrigação que pode ser cumprida sem que recursos do empreendedor sejam recolhidos diretamente ao erário. A obrigação do empreendedor é de apoiar a implantação e manutenção de unidade de conservação(art. 36, caput, da Lei n 9.985). Após, quantificada em dinheiro essa obrigação (alíquota definida de acordo com o grau de impacto ambiental), a mesma pode ser cumprida diretamente pelo empreendedor (sem o ingresso de recursos nos cofres públicos) mediante "elaboração, revisão ou implantação de plano de manejo", "aquisição de bens e serviços necessários à implantação, gestão, monitoramento e proteção da unidade,

\footnotetext{
${ }^{8}$ CARNEIRO, Ricardo. A reserva particular do patrimônio natural - RPPN como beneficiária da compensação ambiental prevista na Lei 9.985/2000. In: FIGUEIREDO, Guilherme José Purvin de (Coord.). Direito Ambiental em debate. Rio de Janeiro: Esplanada, 2004, v. 1, p. 279-289.

${ }^{9}$ BRASIL. Supremo Tribunal Federal. Primeira Turma. Recurso Extraordinário n. 228.800-DF. Relator: Ministro Sepúlveda Pertence. Acórdão de 24 de setembro de 2001. DJ 16/11/2001. p. 021. Bens da União: (recursos minerais e potenciais hídricos de energia elétrica): participação dos entes federados no produto ou compensação financeira por sua exploração (CF, art. 20, e $\S 1$ ô): natureza jurídica: constitucionalidade da legislação de regência (L. 7.990/89, arts. 10 e 60 e L. 8.001/90). 1. O tratar-se de prestação pecuniária compulsória instituída por lei não faz necessariamente um tributo da participação nos resultados ou da compensação financeira previstas no art. 20, § 1o, CF, que configuram receita patrimonial. 2. A obrigação instituída na L. 7.990/89, sob o título de "compensação financeira pela exploração de recursos minerais" (CFEM) não corresponde ao modelo constitucional respectivo, que não comportaria, como tal, a sua incidência sobre o faturamento da empresa; não obstante, é constitucional, por amoldar-se à alternativa de "participação no produto da exploração" dos aludidos recursos minerais, igualmente prevista no art. 20, § 1ำ, da Constituição. Disponível em: <www.stf.jus.br>. Acesso em: 25 de janeiro de 2009.
} 
desenvolvimento de estudos etc."(art.33 do Decreto n.․ 4.340/2002). Tudo isso é incompatível com a noção de preço público.

\section{A compensação ambiental como tributo}

Também não se coaduna a compensação ambiental com natureza de taxa. Consoante o art. 77 do Código Tributário Nacional, taxa é espécie do gênero tributo, cujo fato gerador é o exercício do poder de polícia ou a utilização efetiva ou potencial de serviços públicos efetivos ou divisíveis, prestados ao contribuinte ou postos à sua disposição. Como a compensação ambiental é exigida no âmbito do licenciamento ambiental, alguns autores a entendem como tributo, passível de enquadramento como taxa de polícia ${ }^{10}$. Isso ocorre porque o licenciamento ambiental é uma atividade de polícia do Estado e, como tal, tem seu custo repassado para o empreendedor - para todo empreendedor, não apenas para aqueles cujo empreendimento seja causador de impacto significativo não mitigável/não evitável e sujeito ao EPIA/RIMA -, mediante cobrança da taxa de polícia que, no âmbito federal, é chamada de custo de análise.

Não obstante, o valor pago a título de compensação ambiental não se confunde com a taxa de polícia cobrada pelo licenciamento ambiental, já que não é exigida dos empreendedores pelo fato de utilizarem a "máquina estatal" de polícia, mas em virtude de gerarem, com sua atividade, impacto ambiental significativo e inafastável. O licenciamento ambiental, sim, é uma atividade compulsória, de controle e regramento do uso dos recursos ambientais, ou seja, exercício regular do poder de polícia administrativo. Logo, a contraprestação paga pelo contribuinte quando apresenta o projeto para licenciamento, tem natureza jurídica de taxa. A compensação ambiental, ao revés, não tem o caráter retributivo próprio das taxas, haja vista se tratar de uma forma de reparação de danos a que está sujeito o empreendedor e não uma forma de remuneração do Poder Público por atividade por ele exercida.

Do mesmo modo a compensação ambiental não se reveste da natureza jurídica de taxa de serviço. As taxas de serviço devem ter como fato gerador serviços públicos específicos e divisíveis,

10 "Diante todo exposto, podemos chegar à conclusão de que a "compensação ambiental" criada pela Lei no 9.985/2000, e regulamentada pelo Decreto no 4.340/2002, é um verdadeiro tributo, haja vista se tratar de uma prestação exigida por lei, de caráter pecuniário, compulsória, decorrente de expedição de licenciamento ambiental com significativo impacto, ainda que nos meandros da licitude, e cobrada por um órgão público ambiental". SALIBA, Ricardo Berzosa. A natureza jurídica da "compensação ambiental": vícios de inconstitucionalidades. Revista Interesse Público. Porto Alegre: Notadez, n. 29, 2005, p.197-214. 
prestados ao contribuinte ou postos à sua disposição. Serviços específicos são aqueles que podem ser destacados em unidades autônomas de intervenção, de utilidade ou de necessidade públicas; e divisíveis, quando suscetíveis de utilização, separadamente, por parte de cada um dos usuários. Se a taxa de serviço só pode ser instituída para remunerar um serviço público singular e divisível, onde não houver serviço público não haverá causa para a cobrança da taxa correspondente. Deste modo, a compensação ambiental não é uma taxa de serviço porque não se vislumbra a prestação de serviço público propriamente dito nem no licenciamento ambiental, nem tampouco no ato da exigência da compensação ambiental. Se a compensação ambiental, conforme se demonstrou, não configura serviço público capaz de ensejar cobrança de taxa, muito menos ainda nos casos de implantação de unidades de conservação, tendo em vista que este se trata de um serviço público prestado pelo Estado, mais precisamente pelo órgão de meio ambiente, que possui caráter geral e indivisível, posicionando-se, desse modo, no extremo oposto dos casos de incidência de taxa.

Outros autores defendem a tese de a compensação ambiental seria uma modalidade de contribuição de intervenção no domínio econômico - CIDE, de competência exclusiva da União, cuja previsão está disciplinada no artigo 149 da Constituição Federal. Essa espécie tributária teria uma função de estímulo de determinado setor econômico, num dado momento em que se entenda necessária a presença interventiva do Estado. Por isso, inclusive, sua cobrança deve ser temporária, e não contínua, até porque, como se sabe, na própria Constituição não há nenhum dispositivo que prescreva seja esse tributo cobrado para a manutenção duradoura de alguma ordem. Tal contribuição serve, precipuamente, como um instrumento de intervenção e não de financiamento.

Sustentam Édis Milaré e Priscila Santos Artigas que, se uma categoria de empreendimentos cujo conjunto se integra em decorrência de causarem significativos impactos ao meio ambiente, formando um conjunto específico capaz de afrontar o princípio da defesa do meio ambiente (insculpido no art. 170, VI, da Constituição Federal), legitima-se a intervenção do Estado a exigir a contribuição estampada no art. 149 da Carta Magna. Isso se enquadraria perfeitamente no princípio do poluidor pagador, ao determinar que dado setor econômico, ao arcar com a CIDE, insira em sua cadeia produtiva os custos dos impactos causados ao meio ambiente. De todo modo, entendem os autores que para a instituição desse tributo inominado é exigida a edição de lei complementar, bem como o respeito aos princípios da legalidade e da tipicidade da tributação, incompatíveis com a possibilidade e liberdade de fixação das alíquotas pelo Poder Executivo, previstas no art. 36 da Lei n.으 
9.985/2000, e com a adoção de conceitos indeterminados em matéria de fato gerador e base de cálculo ${ }^{11}$.

A compensação ambiental somente se constituiria em uma CIDE se o Poder Público exigisse de indústrias e demais atividades econômicas sujeitas ao licenciamento ambiental (segmento produtivo) o pagamento de valores monetários (CIDE) pelo fato de desenvolverem atividades econômicas altamente degradadoras (fato gerador), com o objetivo de empregar os valores amealhados no custeio de sua intervenção na ordem econômica, na modalidade incentivo, para benefício ou controle do mesmo segmento produtivo que pagou o tributo, mas não é esse o caso. Mesmo se entendendo que as contribuições de intervenção no domínio econômico são utilizadas pela União para direcionar os contribuintes a certos comportamentos, comissivos ou omissivos, úteis ao interesse coletivo, como instrumento de extrafiscalidade, não se pode aceitar a compensação ambiental como uma CIDE.A compensação ambiental não quer direcionar ou desestimular nenhum comportamento do empreendedor. Sua finalidade é diminuir de alguma forma o prejuízo suportado pela coletividade em virtude dos impactos ambientais não mitigáveis de seu empreendimento ${ }^{12}$.

\section{A compensação ambiental como obrigação econômica decorrente da função socioambiental da propriedade}

A compensação ambiental, na realidade, tem natureza jurídica de obrigação econômica de reparação pelo uso do meio ambiente, entendido esse como um direito intangível de todos a determinada qualidade de vida, à preservação do meio ambiente ecologicamente equilibrado. Isso está expresso no caput do art. 225 da Constituição Federal, que prevê que todos têm direito ao meio ambiente ecologicamente equilibrado, bem de uso comum do povo e essencial à sadia qualidade de vida, impondo-se ao Poder Público e à coletividade o dever de defendê-lo e preservá-lo para as presentes e futuras gerações. Expressa ainda o mesmo artigo, em seu parágrafo terceiro, que as condutas e atividades consideradas lesivas ao meio ambiente sujeitarão os infratores à obrigação de reparar os danos causados.

A compensação ambiental se subsume no âmbito do princípio do usuário pagador ${ }^{13}$. O princípio do usuário-pagador consiste no fato do usuário dos recursos naturais sofrer a incidência de um custo (instrumento econômico) devido à utilização dos bens naturais. Os recursos naturais são

\footnotetext{
${ }^{11}$ MILARÉ, Edis; ARTIGAS, Priscila Santos. Compensação ambiental: questões controvertidas. Revista de Direito Ambiental. São Paulo: Revista dos Tribunais, n. 43, jul.-set., 2006, p. 101-114.

12 BECHARA, Érika. Uma contribuição ao aprimoramento do instituto da compensação ambiental na Lei 9.985/2000. Tese de Doutorado. São Paulo: Pontifícia Universidade Católica, 2007, p. $209-212$.

${ }^{13}$ Dispõe o art. 4o, inc. VII da Lei 6.938/1981 que a Política Nacional do Meio Ambiente visará à imposição "ao usuário, da contribuição pela utilização de recursos ambientais com fins econômicos".
} 
bens da coletividade e o uso destes garante uma compensação financeira para a mesma, não importando se o meio ambiente corre risco ou não de ser poluído. Quando alguém usa um bem que não Ihe pertence - e os bens ambientais, por pertencerem a todos, não pertencem a ninguém com exclusividade - deve dar uma retribuição aos titulares deste bem ou, no caso de bens difusos, aos seus gestores.

Sendo os bens ambientais de uso comum de todos, aquele que se utiliza dos componentes ambientais de forma incomum deverá pagar a conta pelo uso invulgar, ainda que "devolva" o componente ambiental nas mesmas ou em melhores condições do que quando o tomou por empréstimo. Considera-se que, pelo menos por algum momento, teria havido um cerceamento do uso normal do bem ambiental ou, por outro lado, se privilegiou para algum usuário o uso invulgar de um bem que a todos pertence ${ }^{14}$. Antonio Herman Benjamin esclarece que o usuário deve pagar pelo uso do bem ambiental que é de todos para evitar a situação que chama de "subsídio". Isso porque, se o recurso é coletivo e uns poucos o estão utilizando sem qualquer compensação pelo seu esgotamento ou uso, então a conta está sendo coberta pelo público em geral. E, ainda mais grave, a mesma coletividade que não está sendo compensada pelo uso do bem, está suportando as despesas com medidas destinadas a protegê-los ${ }^{15}$.

Consoante a análise econômica do direito, qualquer atividade econômica tem custos, mas somente os custos privados (custos de matéria prima, mão de obra, insumos, etc.) seriam internalizados pelo agente, absorvendo parte dos seus custos sociais. Por outro lado, existiriam outros custos, a exemplo da poluição decorrente do exercício da atividade industrial, que não estariam sendo contabilizados como custos pelo agente poluidor, mas estariam sendo impostos a outros agentes. Assim, haverá externalidade negativa se a atividade de um agente, como um empreendimento, ferir o bem-estar de outros. Isso ocorrerá, por exemplo, quando a poluição da água por agrotóxicos torná-la imprópria para consumo humano, bem como para a dessedentalização de animais, se essa perda não for compensada de alguma forma, a exemplo do pagamento de indenizações, multas, ou qualquer outra forma de ressarcimento dos prejuízos sofridos. Deve ser diferenciado, contudo, o direito de uso de determinados bens ambientais tangíveis e o direito intangível de todos à higidez do meio ambiente equilibrado.

Esses direitos de uso de bens ambientais tangíveis, como o direito sobre os recursos hídricos e o subsolo, são direitos difusos, de toda coletividade - portanto nem públicos, nem privados -,

\footnotetext{
${ }^{14}$ RODRIGUES, Marcelo Abelha. Elementos de direito ambiental. 2. ed. São Paulo: Revista dos Tribunais, 2005, p. 228.

${ }^{15}$ BENJAMIN, Antonio Herman V. e. Responsabilidade civil por dano ambiental. Revista de Direito Ambiental. São Paulo: Revista dos Tribunais, n. 3, 1998, p. 19.
} 
pertencentes indivisivelmente a um número indeterminável de pessoas, ligadas entre si por circunstâncias de fato. Porém, embora sejam difusos esses direitos, incumbindo ao Poder Público e à coletividade o dever de preservá-los (art. 225, CF), a Constituição atribuiu a dominialidade dos bens que Ihes servem de suporte fático ao Poder Público, como é o caso da água (art. 20, III, CF, que trata da União, art. 26, I, CF, que trata dos Estados-membros, e art. 1ํ, I, da Lei n.o 9.433/1997) e do subsolo (art. 176, CF). Deste modo, dada a dominialidade do bem tangível, em relação a esses bens o Poder Público pode estabelecer um preço público pelo seu uso e gerir e administrar esses recursos para fazer frente às suas obrigações de preservação dos recursos ambientais (art. 225, caput, CF).

É o que ocorre no caso da Lei n.o 9.433/1997 (arts. 12 e 19) e no Código de Mineração (art. 20, II, DL n. 227/1967, alterado pela Lei n. 9.314/1996) ${ }^{16} . E m$ ambas as situações, como a Constituição estabelece a dominialidade dos bens que servem de suporte fático ao direito difuso da coletividade sobre os recursos naturais ao Poder Público, justifica-se a cobrança de preço público (por exploração do uso do patrimônio atribuído), cobrança esta que constitui ingresso em pecúnia nos cofres públicos.

Situação distinta é a do direito difuso de todos à higidez do meio ambiente (art. 225, caput, CF) porque nessa hipótese trata-se de um bem jurídico intangível, um direito, ausente toda espécie de patrimonialidade. O direito em referência é atribuído a todos, incumbindo ao Poder Público e à coletividade a sua guarda (art. 225, caput, CF). Deste modo, sendo um direito difuso cuja atribuição é dada a todos e a responsabilidade pela guarda é uma responsabilidade de todos, a atuação do princípio do usuário pagador sobre esse direito se apresenta de maneira diversa. A violação do direito difuso de todos à higidez do meio ambiente ocorre quando um dos coobrigados utiliza-se do direito comum de maneira desarrazoada, ocasionando um significativo impacto ambiental e, deste modo, compromete o direito dos demais titulares à mesma fruição. Trata-se, como bem salientou a decisão do Supremo Tribunal Federal, de uma obrigação de compartilhamento de direito difuso comum ${ }^{17}$, a

\footnotetext{
${ }^{16} \mathrm{Cf}$. ADI n. 2.586-DF, relatada pelo Ministro Carlos Velloso. Acórdão de 15 de maio de 2002. DJ 01.08.2003, p. 101. Disponível em: <www.stf.jus.br>. Acesso em 27 de janeiro de 2009.

${ }^{17}$ Como expresso no voto do Ministro Carlos Ayres Britto na ADI .o 3.378-DF: "entendo que o art. 36 da lei no 9.985/00 densifica o princípio do usuário-pagador, este a significar um mecanismo de assunção da responsabilidade social (partilhada, insiste-se) pelos custos ambientais derivados da atividade econômica". "Nessa ampla moldura, é de se inferir que o fato de, aqui e ali, inexistir efetivo dano ambiental não significa isenção do empreendedor em partilhar os custos das medidas preventivas. Isto porque uma das vertentes do princípio usuário-pagador é a que impõe ao empreendedor o dever de também responder pelas medidas de prevenção de impactos ambientais que possam decorrer, significativamente, da implementação de sua empreitada econômica. (...) a compensação ambiental se revela como instrumento adequado ao fim visado pela Carta Magna: a defesa e a preservação do meio ambiente para as presentes e futuras gerações, respectivamente... não há outro meio eficaz para atingir essa finalidade constitucional senão impondo ao empreendedor o dever de arcar, ao menos em parte, com os custos da prevenção, controle e reparação dos impactos negativos ao meio ambiente.... porque o encargo financeiro imposto (a compensação ambiental) é
} 
ensejar o dever de ressarcimento dos demais, o que ocorre através do mecanismo da compensação ambiental, como a prevista no art. 36 da Lei n.․ 9.985/00.

Nessa perspectiva, deve-se pensar o custo como parte do conteúdo do próprio direito. Se a finalidade do direito é assegurar a sobrevivência da humanidade em longo prazo, com uma efetiva higidez do meio ambiente assegurada a todos, caberá ao princípio ecológico orientar a noção de segurança jurídica e liberdade social. O Estado deverá estabelecer mecanismos de uso sustentável do meio ambiente, que, simultaneamente, assegurem as necessidades dos cidadãos atuais sem sacrificar as necessidades das gerações vindouras; sob pena de acentuar a precariedade das condições de vida.

Verifica-se, então, que o direito de propriedade dos empreendimentos está funcionalizado, consoante os arts. 170, VI e 225, § 3으, da Constituição Federal, a interesses extra proprietários, sobretudo o interesse difuso de todos à higidez do meio ambiente. Este é o sentido da chamada função socioambiental da propriedade. Seu uso só é permitido naquilo que não implique um significativo impacto ambiental, conforme estabelece o art. 170 da CF. Ocorrido este, existe o dever de ressarcimento dos demais coobrigados, atingidos em seu direito difuso à higidez do meio ambiente.

Portanto, a compensação ambiental tem natureza jurídica de obrigação econômica de reparação pelo uso do meio ambiente, entendido esse como um direito intangível de todos a determinada qualidade de vida, à preservação do meio ambiente ecologicamente equilibrado. Ela decorre da função socioambiental da propriedade e será devida toda vez que o uso da propriedade ultrapassar um determinado nível, causando um impacto ambiental significativo, violando, dessa maneira, o direito de todos à higidez do meio ambiente. Esse significativo impacto ambiental será apurado através do EPIA/RIMA, facultando aos proprietários todas as garantias do contraditório e da ampla defesa na apuração desse impacto ambiental.

A compensação ambiental do art. 36 da Lei n.o 9.985/2000 é devida no caso de dano ambiental inevitável e irreversível, devidamente constatado no licenciamento ambiental. A compensação é devida porque o uso intensivo do meio ambiente exige, desde logo, uma reparação mesmo porque não será possível exigir, mais adiante, depois da concretização do impacto negativo, a reversão ao quadro anterior, ou seja, a reparação in natura.

Sendo uma limitação ao exercício da propriedade, decorrente de causas distintas de aplicação do princípio do usuário pagador, a compensação ambiental é cumulável com o preço público cobrado pelo uso do bem ambiental. Assim, o empreendedor pode ser forçado a pagar uma determinada quantia (preço público) como usuário-pagador de um bem ambiental e, concomitantemente, um amplamente compensado pelos benefícios que sempre resultam de um meio ambiente ecologicamente garantido na sua higidez." 
outro quantum como causador de impacto ambiental significativo não evitável (compensação ambiental). É o caso, por exemplo, de uma indústria potencialmente poluidora que despeja seus efluentes líquidos, após o devido tratamento, nos corpos d'água receptores. Por este despejo, pagará à Agência Nacional das Águas - ANA uma certa quantia, a título de retribuição pelo uso da água; pelos impactos não elimináveis apurados no licenciamento ambiental, pagará a retribuição pelo uso do bem ambiental, que não é mais gratuito. Na segunda hipótese, a forma de exercício do direito de propriedade, dificulta a todos a fruição do direito difuso ao meio ambiente hígido e obriga ao ressarcimento. A avaliação do quantum a ser ressarcido é determinada pelo valor do direito ambiental, mas só na medida do impacto causado.

Sendo uma obrigação de caráter econômico e com função de prevenção de danos que podem se mostrar irreversíveis, é irrelevante o fato de ainda não ter ocorrido o dano. O exercício do direito de propriedade do empreendimento só é permitido se ele se compatibilizar com a sua função socioambiental. Não é possível exercitar um direito de propriedade se este causa significativo impacto ambiental não mitigável. Se, em decorrência da implementação de um empreendimento, e mesmo após a adoção de medidas de minimização e mitigação de danos ambientais, ainda restarem significativos impactos ambientais não mitigáveis, tal forma de exercício do direito de propriedade só poderá ser permitida se efetuada a devida compensação dos co-titulares do direito à higidez do meio ambiente (a coletividade). Tal direito, sendo funcional em relação ao direito de propriedade, se liga de modo indelével a ele, limitando os usos permitidos ou, alternativamente, obrigando à compensação ambiental. Deste modo, como obrigação civil de caráter econômico decorrente da função socioambiental da propriedade, a compensação ambiental apresenta as seguintes características: a) o proprietário/empreendedor é o responsável pela sua implementação; b) a legitimidade do projeto deve ser estabelecida antes das medidas compensatórias serem consideradas, ou seja, o empreendimento deve estar em consonância com todas as medidas legais exigíveis de proteção do meio ambiente; c) os impactos deverão ser evitados sempre quando possível ou então mitigados, ou, como última alternativa, compensados, de modo que não há que se falar em compra do direito de poluir (que não existe); d) os impactos deverão ser compensados em habitats de qualidade equivalente; e e) deve-se preferir sempre a compensação física, se esta não for possível, torna-se necessário compensar financeiramente.

Cabe, portanto, quanto à natureza jurídica da compensação ambiental, afastar as considerações que a entendem como reparação de danos ambientais futuros, ou seja, uma reparação 
antecipada ou ex ante, devida em virtude de danos não mitigáveis/não evitáveis, identificados, porém, antes mesmo de sua ocorrência concreta ${ }^{18}$.

Para os adeptos dessa corrente, o sistema da responsabilidade civil comporta a reparação de danos futuros, ainda não causados, porém de ocorrência certa, devidamente antevista. Danos futuros não seriam meros riscos, que podem ou não se concretizar. São danos certos, porém, ainda não concretizados. Naturalmente, para esses autores, a "certeza" do dano futuro não tem a mesma força do dano atual, pois este já existe, podendo ser conhecido no concreto. Por isso, a reparação do dano futuro não se daria apenas mediante a certeza absoluta de sua ocorrência, mas sim a partir de uma certeza "mitigada", ou seja, de uma fortíssima e robusta probabilidade, que, no caso dos danos ambientais, será demonstrada pelo estudo completo, baseado em dados técnicos fornecidos por equipe multidisciplinar e contrastados com análises do órgão ambiental no procedimento de EPIARIMA.

O dano ambiental futuro, na perspectiva da responsabilidade civil, é a expectativa de dano de caráter individual ou transindividual ao meio ambiente. Por se tratar de risco, não há dano atual nem certeza científica absoluta de sua ocorrência futura, mas tão-somente a probabilidade de dano às futuras gerações. Nestes casos, a constatação de alta probabilidade ou probabilidade determinante de comprometimento futuro da função ecológica ou da capacidade de uso humano dos bens ecológicos, ensejaria a condenação do agente às medidas preventivas necessárias (obrigações de fazer ou não fazer), a fim de evitar danos ou minimizar as consequências futuras daqueles já concretizados. Tratase, portanto, de um meio de comunicação voltado para tomadas de decisão jurídica com o escopo de prevenção, controle, observação e formação de vínculos obrigacionais com o futuro (interesses das futuras gerações $)^{19}$.

Verifique-se que, na hipótese, não se trata mais de reparação de dano, objeto precípuo da responsabilidade civil, mas de prevenção de dano, o que é coisa diversa. A atribuição de responsabilização civil objetiva funda-se na teoria do risco concreto, que exige a concretização de danos atuais e concretos. Não há que se falar em responsabilidade civil, em uma efetiva atribuição de

\footnotetext{
18É esta a posição dos seguintes doutrinadores: MACHADO, Paulo Affonso Leme. Direito Ambiental Brasileiro. 14. ed. São Paulo: Malheiros, 2006, p. 791; RODRIGUES, Marcelo Abelha. Aspectos jurídicos da compensação ambiental. Revista de Direito Ambiental. São Paulo: Revista dos Tribunais, n. 46, 2007, p. 130-145, 2007, p. 135 e ss.; MELO, Ana Alice Moreira de. Compensação ambiental. Dissertação de Mestrado. Nova Lima/MG: Faculdade de Direito Milton Campos, 2006, p. 41; SOUZA, Paula da Rin; DORNELlES, Lia D. Chagas. Parecer/AGU/PGF/IBAMA/PROGE no 286, de 20 de junho de 2003, p. 5; BECHARA, Érika. Uma contribuição ao aprimoramento do instituto da compensação ambiental na Lei 9.985/2000. Tese de Doutorado. São Paulo: Pontifícia Universidade Católica, 2007, p. 209-212, p. 226 e ss.

19 CARVALHO, Délton Winter de. Dano ambiental futuro: a responsabilização civil pelo risco ambiental. Rio de Janeiro: Forense Universitária, 2008, p. 127-128.
} 
responsabilidade pela produção do risco, que seja fundada na probabilidade determinante da ocorrência de dano no futuro.

Pensar em responsabilidade civil nessa hipótese significaria cogitar de uma responsabilização fundada na formação de uma nova teoria do risco, o risco abstrato, em que as decisões jurídicas tivessem como problema a produção de riscos, e cujo único elemento passível de avaliação consistisse nas probabilidades ou improbabilidades de seu potencial lesivo. A toda evidência, a matéria, embora tenha contatos com a noção de responsabilidade civil, visa coisa diversa: a precaução e prevenção do dano ambiental ainda não ocorrido.

Nessa hipótese, estar-se-ia saindo do campo da responsabilidade civil objetiva, que incide tãosomente após a concretização do dano ambiental, ou seja, que tem um propulsão post factum, para se preconizar a adoção de uma teoria do risco abstrato, que tem a finalidade e a função sistêmica de permitir a tomada de decisão antes da concretização dos danos, com base na superação da distinção risco/segurança para a distinção risco/perigo (e as distinções subsequentes à face do risco, ou seja, probabilidade/improbabilidade). Teríamos então uma imputação objetiva do dano, matéria que já não poderia estar além da responsabilidade civil.

Há, portanto, para o Direito, além da reparação de danos, uma nova tarefa de investigação, avaliação e gestão de riscos ambientais. A investigação é concretizada na realização de perícias ambientais no processo judicial, enquanto a avaliação dos riscos se dá pela integração entre os conhecimentos científicos e o Direito, formando uma avaliação jurisdicional probabilística destes riscos e de sua tolerabilidade. Já a gestão do risco ambiental se dá pela imposição ao agente de obrigações de adoção de medidas preventivas ou compensatórias com o escopo de evitar a ocorrência de danos ambientais futuros ou equilibrá-los, quando inevitáveis. Considerado como obrigação econômica, esse instituto tem, pelo menos, duas funções estranhas à responsabilização civil: a função de incentivo (modificando previamente os custos e os preços da intervenção no meio ambiente) e a função de redistribuição (uma vez que as receitas vão ser utilizadas para financiar despesas públicas de proteção do ambiente) $)^{20}$.

\section{A COMPENSAÇÃO AMBIENTAL COMO INSTITUTO CONCRETIZADOR DA FUNÇÃO SOCIOAMBIENTAL DA PROPRIEDADE}

$\mathrm{Na}$ esteira das considerações trazidas no presente estudo, os bens ambientais são originariamente destinados pela Constituição a todos em comum. Assim, concorrem a estes o

\footnotetext{
${ }^{20}$ ARAGÃO, Maria Alexandra de Souza. O princípio do poluidor pagador: pedra angular da política comunitária do ambiente. Coimbra: Coimbra, 1997, p. 115.
}

Revista de Direito da Cidade, vol.07, no 02. ISSN 2317-7721 pp.776-803 794 
empreendedor e todos os demais, que são utilizadores do mesmo direito difuso. Sobre a propriedade é reconhecida, como qualidade intrínseca, uma função social, fundada e justificada precisamente pelo princípio da destinação universal dos bens. O homem realiza-se através da sua inteligência e da sua liberdade e, ao fazê-lo, assume como objeto e instrumento as coisas do mundo e delas se apropria. Neste seu agir, está o fundamento do direito à iniciativa e à propriedade individual. Mediante o seu trabalho, o homem empenha-se não só para proveito próprio, mas também para dos outros. 0 homem trabalha para acorrer às necessidades da sua família, da comunidade de que faz parte, e, em última instância, da humanidade inteira, colaborando, além disso, para o trabalho dos outros, numa cadeia de solidariedade que se alarga progressivamente.

A posse dos meios de produção, tanto no campo industrial como agrícola, é justa e legítima, se serve para um trabalho útil; pelo contrário, torna-se ilegítima, quando não é valorizada ou serve para impedir o trabalho dos outros, para obter um ganho que não provém da expansão global do trabalho humano e da riqueza social, mas antes da sua repressão, da ilícita exploração, da especulação, e da ruptura da solidariedade no mundo do trabalho. Semelhante propriedade não tem qualquer justificação, e não pode receber tutela jurídica. Portanto o direito de propriedade não é um absoluto formal, mas só se justifica se a ele é dado um uso social e na medida dessa justificação, mormente naquela classe de bens que não se destinam primordialmente ao mercado, como é o caso dos bens ambientais. Nesse sentido, os bens ambientais são necessários ou úteis ao homem e não se oferecem, na natureza, em condições de uso e em quantidade bastante. A insuficiência gera a necessidade de se encontrar formas de apropriação e uso, convenientemente disciplinadas. A escassez dos bens thes conferiu sentido econômico e exigiu técnicas jurídicas que ordenassem e disciplinassem a posição do homem, em face da coisa, e as relações entre os homens, a respeito dela. Assim, o direito de propriedade é um produto cultural, uma criação da inteligência, considerada adequada à organização da vida em sociedade, isto é, da vida social.

É na esteira deste raciocínio que se baseia a decisão do Supremo Tribunal Federal, que no percuciente voto do Ministro Relator Carlos Ayres Britto na ADI n. 0 3.378, estabeleceu que o art. 36 da Lei n.ㅇ 9.985/00 - que instituiu a compensação ambiental para os empreendimentos que causem significativo impacto ambiental - densifica o princípio do usuário-pagador, este a significar um mecanismo de assunção da responsabilidade social partilhada pelos custos ambientais derivados da atividade econômica. Conforme se observou oportunamente, o STF entendeu que a compensaçãocompartilhamento não seria fixada discricionariamente pelos órgãos públicos ambientais, mas estaria quantificada objetivamente, de acordo com a compostura do impacto ambiental que vier a ser dimensionado estritamente nos dados técnicos do EPIA/RIMA. 
O que significa essa partição de custos ambientais dentro do direito difuso de todos à higidez do meio ambiente e como interpretar essa decisão? A compensação-compartilhamento decorrente do princípio do usuário-pagador ocorre em função da existência, na espécie, de uma externalidade ambiental negativa. As externalidades negativas têm lugar quando a utilização do meio ambiente por um agente econômico tem resultados danosos para a atividade de um outro agente (no caso, os demais titulares do direito à higidez do meio ambiente), sem que haja um mecanismo de mercado de compensação financeira que obrigue o primeiro a indenizar os demais pelos danos sofridos. Como consequência, o primeiro agente tira proveito do meio ambiente, por exemplo, afetando um manguezal com o seu empreendimento, sem arcar com os custos engendrados por essa utilização. Nesse caso, os custos que correspondem aos danos que não podem ser evitados devem ser compensados à coletividade -essa é a compreensão da compensação ambiental pelo STF.

Até a decisão do Supremo, os danos ambientais que não pudessem ser evitados através de medidas mitigadoras no processo de licenciamento ambiental restavam irresarcidos ou insuficientemente compensados através da precificação em 0,5\% do valor do empreendimento, percentual arbitrário que não tinha conexão com o impacto causado. Isso ocorria devido à particular interpretação que se dava até então a esse bem de uso comum do povo. O caráter de bem público coletivo do meio ambiente advém do fato de que seu acesso é livre em razão da inexistência de direitos claros de propriedade e do fato de que seu "consumo" por um indivíduo não impede que ele também seja utilizado por outros. Aliás, os bens e serviços ambientais são frequentemente gratuitos. Não tendo um preço, esses bens e serviços não podem ser objeto de uma alocação ótima e acabam por ser super explorados e degradados. No caso dos bens públicos coletivos, com essa compreensão, a ausência de um "sinal-preço" impede a internalização dos custos de utilização do meio ambiente nos cálculos dos agentes. Atribuir preços aos bens e serviços ambientais é, portanto, necessário para que os agentes possam internalizar seus custos em seus cálculos privados. Essa atribuição é também tarefa tomada pelos economistas, através da chamada "valoração econômica do meio ambiente". Por isso a importância da decisão tomada, que inclui o custo na estrutura do direito difuso à higidez do meio ambiente. O problema, então, do princípio do usuário pagador, no que se refere não aos bens ambientais diretamente utilizados (como é o caso da compensação financeira pelo uso da água), mas sim àqueles indiretamente atingidos (pelo impacto ambiental), é a quantificação do seu valor, que é o valor do não uso.

$\mathrm{Na}$ área ambiental, a compensação do dano não deve se limitar ao valor patrimonial do meio ambiente afetado, mas deve compreender também a estimativa do valor dos serviços que o patrimônio atingido estaria produzindo ou proporcionando à comunidade, a teor análogo ao do art. 
944 do Código Civil, que dispõe que a indenização mede-se pela extensão do dano, na perspectiva do desenvolvimento sustentável.

Há que se pensar a ideia de sustentabilidade no âmbito de uma Economia Ecológica ${ }^{21}$. A sustentabilidade assim concebida pode ser definida como a relação entre sistemas econômicos dinâmicos e sistemas ecológicos dinâmicos, orientada pelos seguintes requisitos: a) que a vida humana possa continuar indefinidamente; b) que o ser humano possa crescer; c) que as culturas humanas possam se desenvolver; e d) desde que os efeitos das atividades humanas permaneçam dentro de limites que impeçam a destruição da diversidade e da complexidade do contexto ambiental $^{22}$. Isso traz a discussão para o âmbito da teoria do valor, ou seja, o de se saber qual a medida de valor aceitável para se quantificar economicamente os fenômenos ecológicos, ou seja, qual o custo do direito ao meio ambiente hígido. Em economia, a discussão sobre o fundamento do valor é secular $^{23}$ e não cabe abordá-la nos limites estreitos desse texto. Interessa-nos apenas, para a determinação dos custos do direito, o valor econômico dos recursos ambientais que tem origem em seus atributos, estejam associados ou não a um valor de uso. Consoante Tolmasquim²4, o valor econômico total de um recurso ambiental (VERA) é o valor que deriva de seus atributos, com a peculiaridade de que esses atributos podem estar ou não associados a um uso. Ele apresenta a seguinte composição:

$V E R A=(V U D+V U I+V O)+V E^{25}$

\footnotetext{
${ }^{21}$ Na perspectiva da sustentabilidade ambiental, o tipo de processo econômico que importa é aquele que produz bens e serviços levando em conta simultaneamente todos os custos que Ihes são inevitavelmente associados (conciliação/compromisso de crescimento econômico com manutenção de sistemas ecológicos). A tarefa de uma ciência da economia de fundamentos ecológicos que vê o sistema econômico como um subsistema de um sistema maior que o contém, impondo uma restrição absoluta à sua expansão. Capital (K) e recursos naturais (RN) são, neste caso, essencialmente complementares. O progresso científico e tecnológico é visto como fundamental para aumentar a eficiência na utilização dos recursos naturais em geral (renováveis e não renováveis) e, nesse aspecto, esta corrente partilha com a primeira a convicção de que é possível instituir uma estrutura regulatória baseada em incentivos econômicos capaz de aumentar esta eficiência.A questão central é, neste sentido, como fazer com que a economia funcione considerando a existência dos limites dos recursos naturais. O mecanismo de ajuste proposto pelo esquema analítico neoclássico desconsidera, por definição, a existência destes limites, supondo a possibilidade de substituição ilimitada dos recursos que se tornam escassos por recursos abundantes.

22 LIMA, Luiz Henrique. Controle do patrimônio ambiental brasileiro: a contabilidade como condição para o desenvolvimento sustentável. Rio de Janeiro: EdUERJ, 2001, p. 140.

${ }^{23}$ Para uma análise percuciente dessa questão, ver: DOBB, Maurice. Teorias do valor e distribuição desde Adam Smith. Lisboa: Presença, 1976.

24 TOLMASQUIM, Mauricio T. Metodologias de valoração econômica do meio ambiente. Rio de Janeiro: Coppe/UFRJ - PPE, 1999.

${ }^{25} \mathrm{Em}$ que:

$\mathrm{VU}=\mathrm{VUD}+\mathrm{VUI}+\mathrm{VO}$

$\mathrm{VU}=$ valor de uso

VUD = valor de uso direto

$\mathrm{VUI}=$ valor de uso indireto
}

Revista de Direito da Cidade, vol.07, no 02. ISSN 2317-7721 pp.776-803 797 
Consoante Luiz Henrique Lima ${ }^{26}$, o valor de uso de um bem ambiental é aquele atribuído pelos indivíduos que realmente o utilizam ou usufruem. Esse bem pode ser de uso direto, como um produto que possa ser consumido diretamente (alimentos, biomassa), ou serem diretos os benefícios que esse bem possa proporcionar (a produtividade de um rebanho). O valor de uso indireto corresponde aos benefícios funcionais que o bem produz ou às funções ecológicas que desempenha (controle de enchentes), produzindo algum efeito positivo sobre outros recursos.

O valor de opção de um bem ambiental é aquele atribuído pelos indivíduos que, sem utilizá-lo no presente, pretendem conservá-lo para potencial uso futuro, tanto para si mesmos, como para as futuras gerações. Como exemplo, pode-se citar o valor atribuído à Antártida ou à Amazônia por muitos que jamais irão utilizá-las diretamente. O conceito de valor de quase-opção também é mencionado pelo Banco Mundial que o explica como sendo o que decorre da possibilidade de que algo que hoje não aparente ter um valor significativo possa vir a tê-lo no futuro, em virtude de novas informações ou descobertas científicas. Já o valor de existência de um bem ambiental é aquele atribuído pelos indivíduos independentemente de seu uso atual ou futuro. Há vários motivos que o explicam, desde o desejo de ofertar o meio ambiente para as gerações futuras, até a simpatia por espécies ou animais, fundamentada no sentimento ético de direito à existência dos não humanos. Encontram-se nesse caso os valores atribuídos à preservação de ursos pandas ou baleias. O conceito de valor de existência representa uma "ponte" que liga economistas a ecologistas. A cada parcela componente do valor econômico total correspondem uma ou várias técnicas de valoração.

Dentre os vários métodos de valoração desenvolvidos - respectivamente divididos em métodos da função de produção ${ }^{27}$ e métodos da função de demanda ${ }^{28}$ - destaca-se o método de valoração contingente (MVC), que procura mensurar monetariamente o impacto no nível de bemestar dos indivíduos decorrente de uma variação quantitativa ou qualitativa dos bens ambientais. Esta

VO = valor de opção

$\mathrm{VE}=$ valor de existência

${ }^{26}$ LIMA, Luiz Henrique. Controle do patrimônio ambiental brasileiro: a contabilidade como condição para o desenvolvimento sustentável. Rio de Janeiro: EdUERJ, 2001, p. 161.

27 Métodos da função da produção - são esses os métodos da produtividade marginal e de mercados de bens substitutos (custo de reposição/reparação, custos de re-localização, despesas de proteção, despesas de proteção/mitigação). Se o recurso ambiental é um insumo ou um substituto de um bem ou serviço privado, estes métodos utilizam-se de preços de mercado deste bem ou serviço privado para estimar o valor econômico do recurso ambiental.

28 Métodos da função da demanda - métodos de mercado de bens complementares (preços hedônicos e do custo de viagem) e método da valoração contingente.Estes métodos assumem que a variação da disponibilidade do recurso ambiental altera a disposição a pagar ou aceitar dos agentes econômicos em relação aquele recurso ou seu bem privado complementar. Estimam diretamente os valores econômicos (preços-sombra) com base em funções de demanda para estes recursos derivadas de (i) mercados de bens ou serviços privados complementares ao recurso ambiental ou (ii) mercados hipotéticos. 
abordagem baseia-se na premissa de que os consumidores podem e irão revelar sua real disposição a pagar por bens que não são de mercado dentro de um mercado hipotético. Uma das vantagens desse tipo de metodologia consiste justamente em produzir estimativas de valores que não poderiam ser obtidos por outros meios. Tais bens incluem, por exemplo, a preservação de espécies, estética ambiental, fenômenos históricos ou diversidade genética. Em comparação com outros métodos de mercado de bens complementares (preço hedônico e custo de viagem), não é necessário estimar uma curva de demanda de um benefício para se obter o valor monetário que está associado a este benefício proporcionado pelo bem ou serviço ambiental.

O interesse por este método tem crescido bastante ao longo da última década e, entre outros motivos, destaca-se o próprio aperfeiçoamento das pesquisas de opinião e, principalmente, o fato de ser a única técnica com potencial de captar o valor de existência. Por outro lado, a aplicação desta técnica não é trivial e também envolve custos elevados de pesquisa.

Neste sentido, busca-se simular cenários, cujas características estejam o mais próximo possível das existentes no mundo real, de modo que as preferências reveladas nas pesquisas reflitam decisões que os agentes tomariam de fato, caso existisse um mercado para o bem ambiental descrito no cenário hipotético. As preferências, do ponto de vista da teoria econômica, devem ser expressas em valores monetários. Estes valores são obtidos através das informações adquiridas nas respostas relativas ao número de indivíduos que estariam dispostos a pagar para garantir a melhoria de bemestar, ou o quanto estariam dispostos a aceitar em compensação para suportar uma perda de bemestar. Finalmente, conforme apresentado, existem diversas técnicas de avaliar os impactos que podem ser aplicadas sob certas circunstâncias. A escolha do melhor método depende do bem a ser valorado, dos dados disponíveis e também dos objetivos propostos.

Nada obstante, o objetivo da valoração contingente é tornar perceptíveis as preferências dos consumidores através da revelação de sua disposição a pagar (DAP) pelo bem natural. O método estima o valor da disposição a pagar (DAP) com base em mercados hipotéticos. A simulação destes mercados é realizada através de pesquisas de campo, com questionários, que indagam a sua valoração contingente (VC) em face de alterações na disponibilidade de recursos ambientais.

A grande vantagem deste método, em relação aos demais ${ }^{29}$, é a sua possibilidade de ser aplicado a um espectro de bens ambientais mais amplo, e de ser a única técnica com potencial de captar o valor de existência. Por outro lado, as críticas ao método envolvem a sua limitação em captar valores ambientais que indivíduos não entendam ou desconhecem, elevados custos de pesquisa e

\footnotetext{
${ }^{29}$ Neste particular, outros métodos possíveis seriam o Custo de Viagem (MCV), o Valor de Propriedade ou de Preços Hedônicos, o Despesas de Prevenção/Mitigação, o Despesas de Proteção, o Custos de Re-Localização, o Custo de Reposição/Reparação e o método de Produtividade Marginal.
} 
resultados enviesados caso certos procedimentos não sejam corretamente obedecidos. Assim, os tribunais, em secular evolução, pelo desenvolver da jurisprudência foram determinando não só a extensão progressiva da indenização à totalidade dos casos de danos morais, mas também os parâmetros pelos quais estes poderiam ser estimados e avaliados.

Idêntica situação se apresentará agora na compensação ambiental na determinação da valoração dos bens ambientais através do princípio do usuário pagador. Caberá ao Poder Judiciário, paulatinamente, em cada caso, desenvolver um instrumental adequado de quantificação monetária do dano ambiental, tal como hoje existe para o dano moral. É sabido que estes parâmetros jamais poderão ser rígidos e inflexíveis, tais como não o são os parâmetros de quantificação do dano moral.

Não obstante, pela prática jurídica, é possível se estabelecer parâmetros de valoração que recebam a aceitação regular dos estamentos jurídicos e que, pela consensualidade, possam ser identificados como válidos nos Tribunais. Os conceitos jurídicos indeterminados são inerentes ao direito ambiental. A lei não é o instrumento adequado para fixar a compensação de um dano ambiental, visto que a proporcionalidade não pode jamais ser congelada pela norma. Sua aferição darse-á casuisticamente, de acordo com o caso concreto, sempre guardando uma pertinência lógica entre o impacto e a compensação, garantindo-se o contraditório e a ampla defesa.

A decisão do Supremo Tribunal Federal relativizou o poder discricionário dos órgãos ambientais, abrindo uma maior oportunidade para que o empreendedor interessado possa questionar os critérios adotados. Suprimidos os limites mínimos e máximos fixados pela norma, terá o empreendedor maior espaço para dialogar na escolha das medidas compensatórias da sua atividade, assim como, por outro lado, confere-se ao órgão ambiental a tarefa de decidir com base em critérios técnicos razoáveis e proporcionais. Na prática, a determinação do STF reforça a importância do Estudo Prévio de Impacto Ambiental/Relatório de Impacto Ambiental (EPIA/RIMA), uma vez que cabe ao órgão licenciador - municipal, estadual ou federal - definir o valor da compensação, de acordo com o impacto ambiental a ser dimensionado no EPIA/RIMA. Ainda segundo o STF, o órgão ambiental "não poderá, arbitrariamente, definir o valor (da compensação), uma vez que deverá agir sob o manto da legalidade, impessoalidade, moralidade, publicidade e eficiência. Deve, isto sim, fixar o quantum compensatório em estrita conformidade com os dados técnicos do EIA/RIMA".

O consenso em torno da metodologia da valoração dos bens ambientais na aplicação em cada caso do princípio do usuário pagador se fará então, paulatinamente, (como na determinação do dano moral), sempre com o direito ao contraditório e à ampla defesa, através de uma interação dialética entre o Poder Público, os empreendedores e as organizações da sociedade civil, até que se possa estabelecer uma razoável unidade em torno dos parâmetros de valoração. 


\section{CONCLUSÃO}

De tudo o que foi exposto pode-se concluir sucintamente, no que se refere à essa emanação da função socioambiental da propriedade que é a compensação ambiental como uma decorrência do princípio do usuário pagador:

1. O meio ambiente é uma totalidade e, nesse sentido, se constitui num macrobem, sendo sua natureza é a de uma coisa comum a todos (communium ominium). Desta forma, a complexidade do conceito de bem ambiental, seu caráter holístico, irão suscitar novas soluções de direito. Superado o entendimento do meio ambiente como res nullius e revelada a insuficiência da simples patrimonialização pública sem controle de gestão dos usos do bem ambiental, cabe agora repensá-lo a partir de seu escopo, de sua função, protegendo-o em vista de suas finalidades.

2. Atualmente entende-se que o proprietário do bem socioambiental, ou seja, daquele bem essencial para a manutenção da vida das espécies, fica obrigado a um comportamento ativo, que envolve defender, reparar e preservar o meio ambiente. O proprietário não pode exercer o seu direito de forma contrária aos interesses da presente e das futuras gerações, causando danos à qualidade de vida e consequentemente ao próprio direito fundamental à vida.

3. A função socioambiental da propriedade está claramente contemplada nos arts. 225 e 170 da Constituição Federal. Correlacionando-a com o instituto da compensação ambiental, verificase que o direito de propriedade deverá ser exercido em função do direito de toda a coletividade a um meio ambiente ecologicamente equilibrado. Este só merecerá tutela jurídica enquanto funcionalizar esse direito difuso de todos.

4. Na esteira destas premissas, verifica-se que a disciplina da compensação ambiental - instituto que prevê mecanismos compensatórios quando da realização de empreendimento causador de significativo impacto ambiental - foi substancialmente alterada pela decisão do Supremo

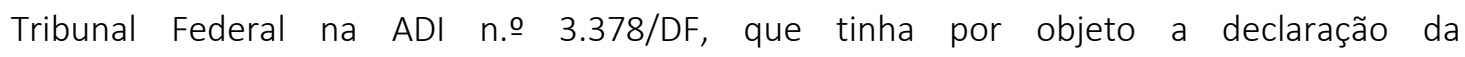
inconstitucionalidade do art. 36 e seus $\S \S 1$ ㄴ, 2o e 3으, da Lei n.o 9.985/2000.

5. No acórdão do referido precedente, a Corte -explícita ou implicitamente - fixou o entendimento de que a compensação ambiental decorre da desconformidade para com o fim econômico-social para o qual o direito de propriedade foi instituído.

6. Através da noção de usuário-pagador, a compensação ambiental não se caracteriza, portanto, como uma punição, pois mesmo não existindo qualquer ilicitude no comportamento do pagador poderá ser implementada. Assim, para tornar obrigatório o pagamento pelo uso do 
recurso, pela sua poluição ou degradação não há necessidade de ser provado que o usuário e o poluidor estão cometendo faltas ou infrações - de modo que a função precípua da compensação ambiental não é a reparação dos danos causados, "voltada para o passado", própria da responsabilidade civil, mas a prevenção de danos grave e, por vezes, irreversíveis, orientada para o futuro.

7. Em conclusão, destarte, deve-se entender, em termos de prevenção, que a compreensão de que os recursos naturais são considerados bens livres e de acesso irrestrito por parte de todos acelera a escalada da degradação do meio ambiente, frente ao processo de utilização abusiva destes recursos. E, um dos fatores que contribuem para a escassez dos bens ambientais é a economia do desperdício, porque não há limitação monetária para a utilização dos recursos naturais e nem um sistema de regeneração dos mesmos. A função preventiva da compensação ambiental visa a alterar esse estado de coisas.

\section{REFERÊNCIAS}

ARAGÃO, Maria Alexandra de Souza. O princípio do poluidor pagador: pedra angular da política comunitária do ambiente. Coimbra: Coimbra, 1997.

BECHARA, Érika. Uma contribuição ao aprimoramento do instituto da compensação ambiental na Lei 9.985/2000. Tese de Doutorado. São Paulo: Pontifícia Universidade Católica, 2007.

BENJAMIN, Antonio Herman V. e. Responsabilidade civil por dano ambiental. Revista de Direito Ambiental. São Paulo: Revista dos Tribunais, n. 3, 1998.

BRASIL. Supremo Tribunal Federal. ADI n.o 2.586-DF, relatada pelo Ministro Carlos Velloso. Acórdão de 15 de maio de 2002. DJ 01.08.2003. Disponível em: <www.stf.jus.br>. Acesso em 18 de maio de 2015.

Primeira Turma. Recurso Extraordinário n. 228.800-DF. Relator: Ministro Sepúlveda Pertence. Acórdão de 24 de setembro de 2001. DJ 16/11/2001. Disponível em: <www.stf.jus.br>. Acesso em: 18 de maio de 2015.

CARNEIRO, Ricardo. A reserva particular do patrimônio natural - RPPN como beneficiária da compensação ambiental prevista na Lei 9.985/2000. In: FIGUEIREDO, Guilherme José Purvin de (Coord.). Direito Ambiental em debate. Rio de Janeiro: Esplanada, 2004.

CARVALHO, Délton Winter de. Dano ambiental futuro: a responsabilização civil pelo risco ambiental. Rio de Janeiro: Forense Universitária, 2008.

DOBB, Maurice. Teorias do valor e distribuição desde Adam Smith. Lisboa: Presença, 1976.

GALDINO, Flávio. Introdução à teoria dos custos dos direitos: direitos não nascem em árvores. Rio de Janeiro: Lumen Juris, 2005. 
GUERRA, Sérgio. Compensação ambiental nos empreendimentos de significativo impacto. In: WERNECK, Mário et alli (Coords.). Direito ambiental visto por nós advogados. Belo Horizonte: Del Rey, 2005.

LEMOS, Patrícia Faga Iglecias. Meio ambiente e responsabilidade civil do proprietário: análise do nexo causal. São Paulo: Revista dos Tribunais, 2008.

LIMA, Luiz Henrique. Controle do patrimônio ambiental brasileiro: a contabilidade como condição para o desenvolvimento sustentável. Rio de Janeiro: EdUERJ, 2001.

MACHADO, Paulo Affonso Leme. Direito Ambiental Brasileiro. 14. ed. São Paulo: Malheiros, 2006.

MELO, Ana Alice Moreira de. Compensação ambiental. Dissertação de Mestrado. Nova Lima/MG: Faculdade de Direito Milton Campos, 2006.

MILARÉ, Edis; ARTIGAS, Priscila Santos. Compensação ambiental: questões controvertidas. Revista de Direito Ambiental. São Paulo: Revista dos Tribunais, n. 43, jul.-set., p. 101-114, 2006.

RODRIGUES, Marcelo Abelha. Aspectos jurídicos da compensação ambiental. Revista de Direito Ambiental. São Paulo: Revista dos Tribunais, n. 46, 2007, p. 130-145, 2007.

RODRIGUES, Marcelo Abelha. Elementos de direito ambiental. 2. ed. São Paulo: Revista dos Tribunais, 2005.

SALIBA, Ricardo Berzosa. A natureza jurídica da "compensação ambiental": vícios de inconstitucionalidades. Revista Interesse Público. Porto Alegre: Notadez, n. 29, p.197-214, 2005.

SOUZA, Paula da Rin; DORNELLES, Lia D. Chagas. Parecer/AGU/PGF/IBAMA/PROGE no 286, de 20 de junho de 2003.

TOLMASQUIM, Mauricio T. Metodologias de valoração econômica do meio ambiente. Rio de Janeiro: Coppe/UFRJ - PPE, 1999.

Trabalho enviado em 21 de junho de 2015.

Aceito em 27 de junho de 2015. 